\title{
INSECT IMMUNITY : THE DIPTERICIN PROMOTER CONTAINS MULTIPLE FUNCTIONAL REGULATORY SEQUENCES HOMOLOGOUS TO MAMMALIAN ACUTE-PHASE RESPONSE ELEMENTS
}

\author{
Philippe Georgel, Marie Meister, Christine Kappler, Bruno Lemaitre, \\ Jean-Marc Reichhart and Jules A. Hoffmann*
}

Laboratoire de Biologie Générale, Bases Cellulaires et Moléculaires de la Réponse Immunitaire des Insectes, UA CNRS 1490, 12 rue de l'Université, F-67000 Strasbourg, France

Received October 7, 1993

We are using the diptericin gene as a model system to study the control of expression of the genes encoding antibacterial peptides during the Drosophila immune reaction. In order to investigate the putative regulatory regions in the diptericin promoter, we performed DNaseI footprinting experiments combined with gel-shift assays in two inducible systems : the larval fat body and a tumorous Drosophila blood cell line. Our results confirm the importance of $\kappa \mathrm{B}$-like elements previously described in the immune response of insects and reveal for the first time the involvement of other regions containing sequences homologous to mammalian acute-phase response elements.

- 1993 Academic Press, Inc.

One of the facets of the potent antibacterial defense reaction in insects is the rapid and transient synthesis following bacterial challenge of a battery of antibacterial molecules (reviewed in ref.1). These are mostly small-sized cationic peptides with a large spectrum of activity against Gram positive and/or Gram negative cells. The synthesis of these peptides takes place predominantly in the fat body and in some blood cells. The insect host defense does not exhibit the hallmarks of the mammalian lymphocyte response, i.e. specificity and memory. In contrast, it shares many of the characteristics of the mammalian acute phase response $(1,2,3)$.

We are interested in the control of the expression of the genes encoding the antibacterial peptides during the Drosophila host defense reaction and have selected the diptericin gene $(4,5)$ as an experimental model system. The gene is strongly expressed in larvae and adults 1-2 $\mathrm{h}$ after bacterial challenge and is rapidly induced in a tumorous blood cell line of Drosophila

${ }^{*}$ To whom correspondence should be addressed. Fax: 88-24-04-61. 
( $m b n-2$, see ref.6) by addition of bacteria or lipopolysaccharides (LPS) to the culture medium $(7,8)$. The upstream sequences of this gene contain several motifs with sequence similarities to mammalian immune gene response elements, namely to binding motifs for $\mathrm{NF}-\mathrm{kB}$ and for proteins conferring IL-6 inducibility (NF-IL-6 and IL-6 RE-BP, see ref.9,10). Of particular interest in this promoter are two decameric $\mathrm{kB}$-related sequences located closely upstream of the TATA-box. These motifs are nested within two 17-bp repeats and are mandatory for the inducibility of the diptericin gene by bacterial challenge (8).

In the present study we have analysed the potential role in the transcriptional control of the diptericin gene of other binding sites located in the proximal upstream sequences of the gene. For this, we have tested by DNaseI footprinting studies and electrophoretic mobility shift assays, the ability of proteins from induced Drosophila to bind to the proximal promoter regions. Our results confirm the role of the $\mathrm{k} B$-related motifs, and show that multiple, frequently redundant and overlapping cis-regulatory sequences, and various transactivators are involved in the immune induction of this gene.

\section{MATERIALS AND METHODS}

Bacterial challenge of Drosophila and LPS treatment of tumorous blood cells Third instar larvae of Drosophila melanogaster (Oregon ${ }^{\mathrm{R}}$ strain) were pricked with a needle dipped into a concentrated culture of Escherichia coli and Micrococcus luteus, and replaced on standard medium at $25^{\circ} \mathrm{C}$ for $4 \mathrm{~h}$. Tumorous blood cells ( $m b n-2$, see ref. 6) were grown at $25^{\circ} \mathrm{C}$ in Schneider's medium (Sigma) supplemented with $10 \%$ fetal calf serum (Gibco BRL), 105 $\mathrm{U} / \mathrm{p}$ penicillin and $100 \mathrm{mg} / \mathrm{l}$ streptomycin. Cells were treated for $4 \mathrm{~h}$ with 10 $\mu \mathrm{g} / \mathrm{ml}$ of LPS (Difco, $E$. coli 55:B5).

\section{Preparation of protein extracts}

Fat bodies of control or immunized insects were hand-dissected and homogenized in buffer A (10 mM HEPES pH 7.9, $1 \mathrm{mM} \mathrm{CaCl} 2,0.3 \mathrm{M}$ sucrose, $10 \mathrm{mM} \mathrm{KCl}, 0.5 \mathrm{mM}$ DTT, $0.5 \mathrm{mM}$ PMSF). Nuclei were collected by a 10 min centrifugation at $1,500 \mathrm{~g}$ and proteins were extracted by high salt in buffer $\mathrm{B}$ ( $10 \mathrm{mM}$ HEPES $\mathrm{pH} 7.9,500 \mathrm{mM} \mathrm{NaCl}, 1 \mathrm{mM}$ EGTA, $1 \mathrm{mM}$ EDTA, $10 \%$ glycerol, $0.5 \mathrm{mM}$ DTT, $0.5 \mathrm{mM}$ PMSF). After a $30 \mathrm{~min}$ centrifugation at $10,000 \mathrm{~g}$, the nuclear extract was dialysed against buffer $\mathrm{C}$ (20 mM HEPES pH 7.9, $25 \mathrm{mM} \mathrm{NaCl}, 25 \mathrm{mM} \mathrm{KCl,} 0.1 \mathrm{mM}$ EDTA, $0.5 \mathrm{mM}$ DTT, $0.1 \mathrm{mM}$ PMSF, $20 \%$ glycerol, $0.05 \%$ NP40). Proteins were quantified with the Bradford assay. Nuclear extracts of $m b n-2$ cells were prepared according to Dignam et al. (11) and were dialysed against buffer C.

\section{DNase I footprint}

PCR probes were prepared as described in the protocol of Krummel (12).

Different amounts of protein extract (see figure legends) were mixed with the uniquely end-labeled DNA fragments in buffer $\mathrm{C}$ supplemented with 3 $\mathrm{mM} \mathrm{MgCl} 2$. DNAse I (100 ng) was added and the mixture was incubated 90 $\mathrm{sec}$ at $20^{\circ} \mathrm{C}$ before addition of the stop solution $(0.3 \% \mathrm{SDS}, 140 \mathrm{mM} \mathrm{NaCl}$, 
$50 \mathrm{mM}$ Tris- $\mathrm{HCl} \mathrm{pH} 8.0,50 \mu \mathrm{g} / \mathrm{ml}$ tRNA). After phenol/chloroform extraction, DNA was ethanol-precipitated, resuspended in blue dye and loaded on a $8 \%$ polyacrylamide / 8M Urea sequencing gel. Naked DNA was digested for $60 \mathrm{sec}$ with $4 \mathrm{ng}$ of DNaseI.

Electrophoretic mobility shift assay

Proteins (see figure legends) were mixed with $2 \mu \mathrm{g}$ of poly dA/dT in buffer $\mathrm{C}$ (in which glycerol was replaced by $4 \%$ Ficoll) to give a final volume of $20 \mu \mathrm{l}$. Preincubation was for $10 \mathrm{~min}$ at $0^{\circ} \mathrm{C}$ before the addition of $20,000 \mathrm{cpm}$ of labeled double stranded oligonucleotide for $15 \mathrm{~min}$ at $20^{\circ} \mathrm{C}$. The complexed and free DNA were resolved on a $5 \%$ (40:1 cross-linking ratio) polyacrylamide gel in $0.5 \mathrm{X}$ TBE (45 mM Tris- $\mathrm{HCl} \mathrm{pH} 7.5,45 \mathrm{mM}$ boric acid, 1 mM EDTA).

The double-stranded oligonucleotides corresponding to the footprinted regions which were used in this study were the following (only the upper strand is given below):

oligo I 5' AGATAAGGTGACATCGGGGATTCCTTTTGGAAAGCGGCCTATAAA ${ }^{3}$

oligo II 5' ATCGGGGATTCCTTTT ${ }^{\prime}$

oligo III $5^{\prime}$ TCCTCGTTTAAGAAAGATCCC ${ }^{3}$

oligo IV/V 5' CTTGTTTGTCAAATGAAATAAGGTGT 3 '.

\section{RESULTS}

\section{DNA binding activities in bacteria-challenged larvae.}

The ability of proteins from induced Drosophila to bind to the proximal promoter regions was first tested by a DNaseI footprinting approach. A 401 bp fragment of the promoter from positions -324 to +77 was end-labeled and incubated with proteins extracted from fat body of control or bacteriachallenged third instar larvae. Five regions (Fig.1, I to V) were protected with fat body extracts of challenged larvae. Extracts from controls gave no protection. The sequences of the footprinted regions are presented in Fig. 5. Region I extends over $30 \mathrm{bp}$ and contains three motifs related to established binding elements of mammalian immune response genes, namely : an interferon consensus response element (ICRE, ref.13) and sequences related to binding sites for NF-IL6 (9) and NF-kB (14); these potential binding sites are partially overlapping. Region II contains a second, identical, $\mathrm{kB}$-related binding site; region III an additional site related to the mammalian NF-IL6 binding site and region IV a second interferon consensus response element. In region $\mathrm{V}$, a sequence is present which is frequently associated with liverspecific expression in mammalian genes where it binds the activator HNF-5 (Hepatic Nuclear Factor 5, ref.15).

We have next incubated labeled double-stranded oligonucleotides I to IV/N with protein extracts from fat body of normal and bacteria-challenged third instar larvae. The protein-DNA complexes were separated from free probe by electrophoretic mobility shift assay on the same gel for all four sets of probes. Several complexes were evidenced (Fig.2), some of which are clearly induced by bacterial challenge. Probe II which is a $\mathrm{kB}$-related site 


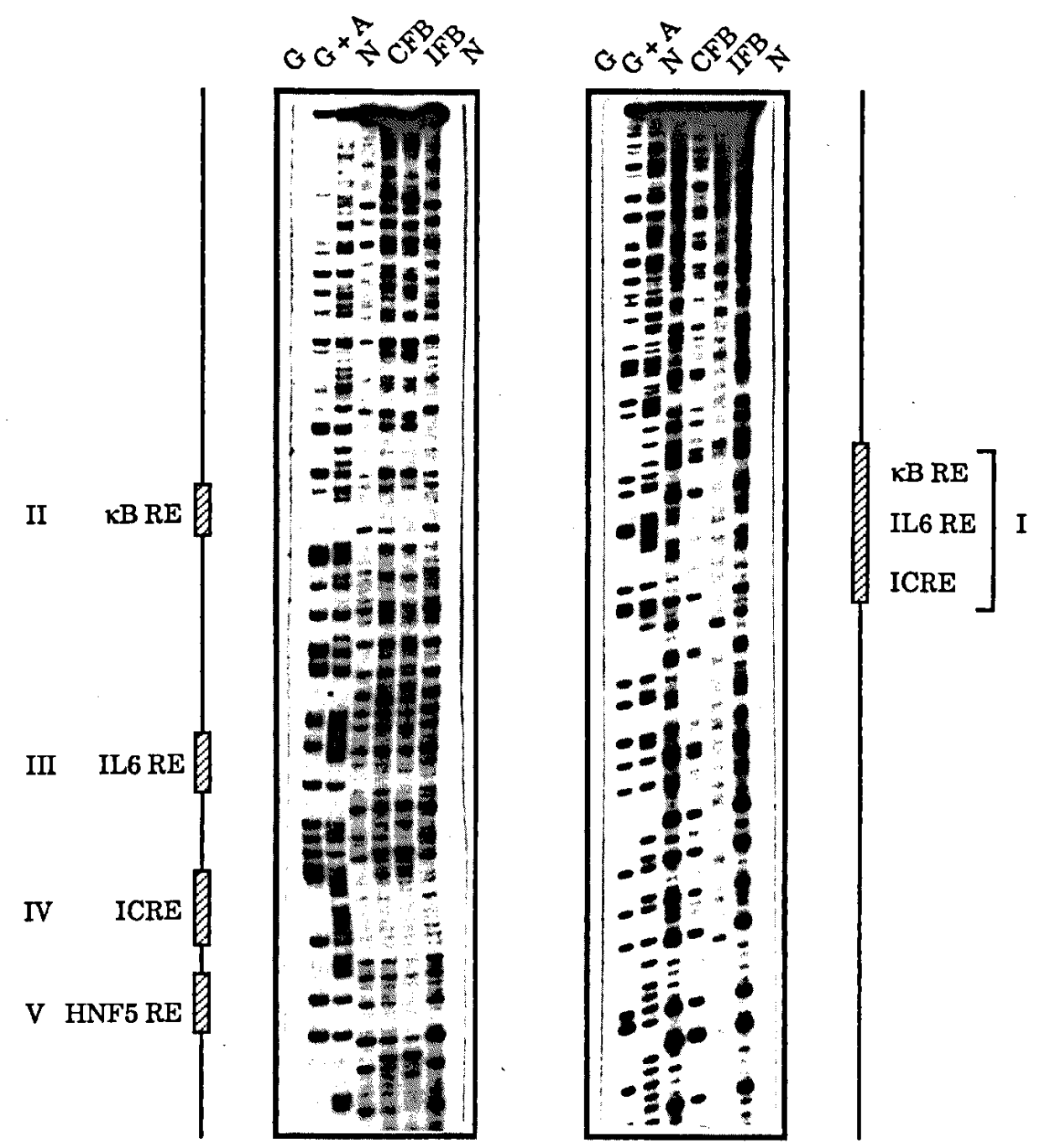

Figure 1. Footprint analysis of the diptericin promoter with larval fat body proteins. $10 \mu \mathrm{g}$ of proteins of control (CFB) or induced (IFB) fat body was incubated with the uniquely end-labeled probe. $G$ and $G+A$ are Maxam and Gilbert sequencing reactions and $\mathrm{N}$ is naked DNA. On each side are indicated the protected regions (I to V).

forms two complexes : the slowly migrating complex is induced by bacterial challenge, whereas the faster migrating complex is enhanced by the challenge (compare lanes 7-8). Both are depleted by excess of unlabeled probe I and II (lanes 9-10). The faster migrating complex is also competed by an excess of probes III and IV $/$ (lanes 11-12) and this fact might reflect the existence of possible protein-protein interactions. The induced complex corresponds to that which we had evidenced in our previous study (8) in induced fat body with the $\mathrm{kB}$-related probe and which was shown to have an estimated molecular weight of $75-80 \mathrm{kDa}$ by UV-crosslinking. Probe I gives two specific complexes which are inducible by bacterial challenge and are competed by probe excess (lanes 1-3). These complexes are also competed by 


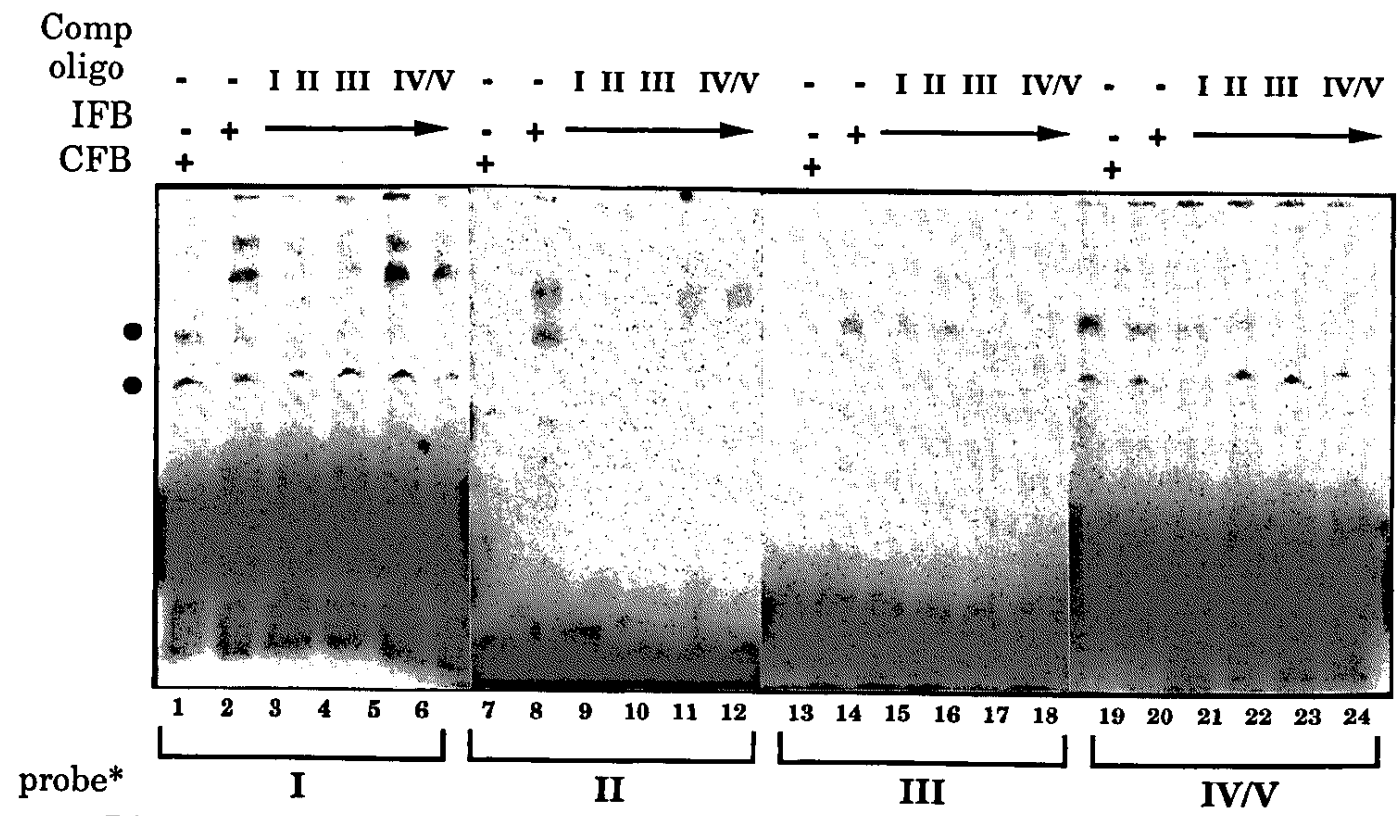

Figure 2. Gel shift assay with fat body proteins and the labeled oligonucleotides I to IV $/ \mathrm{V} .3 \mu \mathrm{g}$ of proteins of control (CFB) or induced (IFB) fat body was used. For the competition experiments, a 100-fold molar excess of the indicated cold probe (Comp oligo) was added before the addition of the labeled oligonucleotide. Black circles indicate nonspecific complexes.

an excess of probe II (lane 4) which indicates that the proteins forming these complexes probably interact with the $\mathrm{kB}$-like sequence. The slowly migrating complex is slightly competed by an excess of probes III and IV/V (lanes 5-6) which is consistent with the fact that theses probes contain sequence elements which are also present in probe I. With probe III a faint complex is evidenced which is enhanced in bacteria-challenged larvae (lanes 13-14); this complex seems to be competed by an excess of all four probes, but a longer exposure of the gel (not shown) reveals that this complex is in fact essentially competed by probes I and III. Finally, with probe IV/N, we were able to detect one specific constitutive complex which was mainly competed by an excess of probes I and IV/V (lanes 19-24). This complex probably reflects the presence in the probe of an HNF-5 binding site which can bind a constitutive (fat body-specific?) polypeptide. The fact that this complex has not been evidenced in uninduced extracts by the footprint analysis might be due to the differences in the binding conditions in these experiments.

\section{DNA-binding activities in LPS-induced mbn-2 cells.}

Footprint experiments performed with nuclear extracts of control or LPS-induced cells yielded results (Fig.3) similar to those obtained with larval fat body extracts, with the marked exception of region III which was 

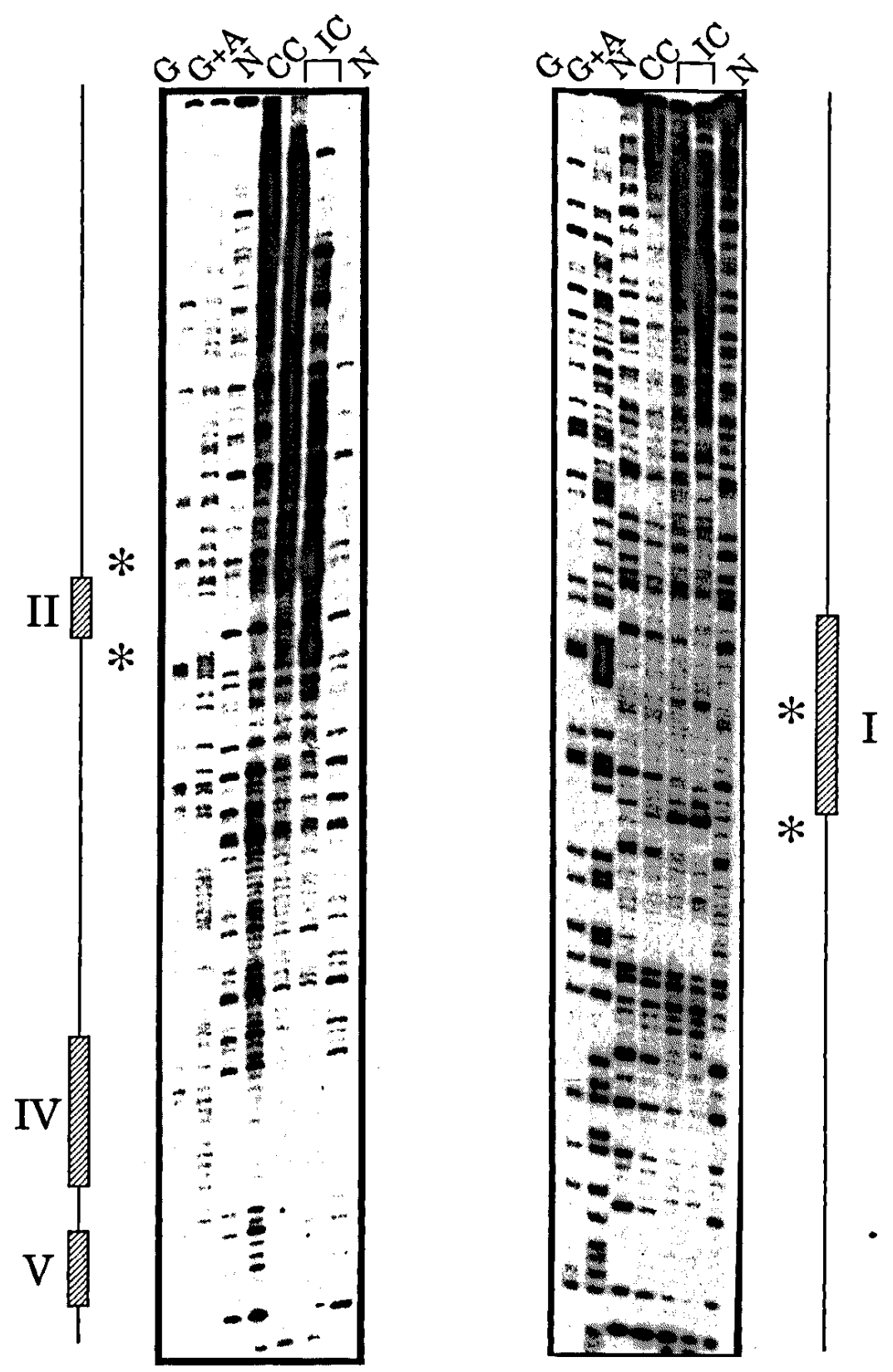

Figure 3. Footprint analysis of the diptericin promoter with mbn-2 cells proteins. $10 \mu \mathrm{g}$ of control extract (CC) of uninduced cells or 10 and 15 $\mu \mathrm{g}$ of an extract of LPS-treated cells (IC) was used. Stars indicate the presence of hypersensitive sites.

not protected. The protection observed with region I appeared somewhat different as a hypersensitive site (marked by a star) becomes apparent which separates the footprint into two parts.

We have next perfomed gel shift assays with induced and uninduced $m b n-2$ cell extracts in the presence of probes I to IVN (Fig.4). Probe I shows the inducibility of two DNA-protein complexes (lanes 1-2) which are 


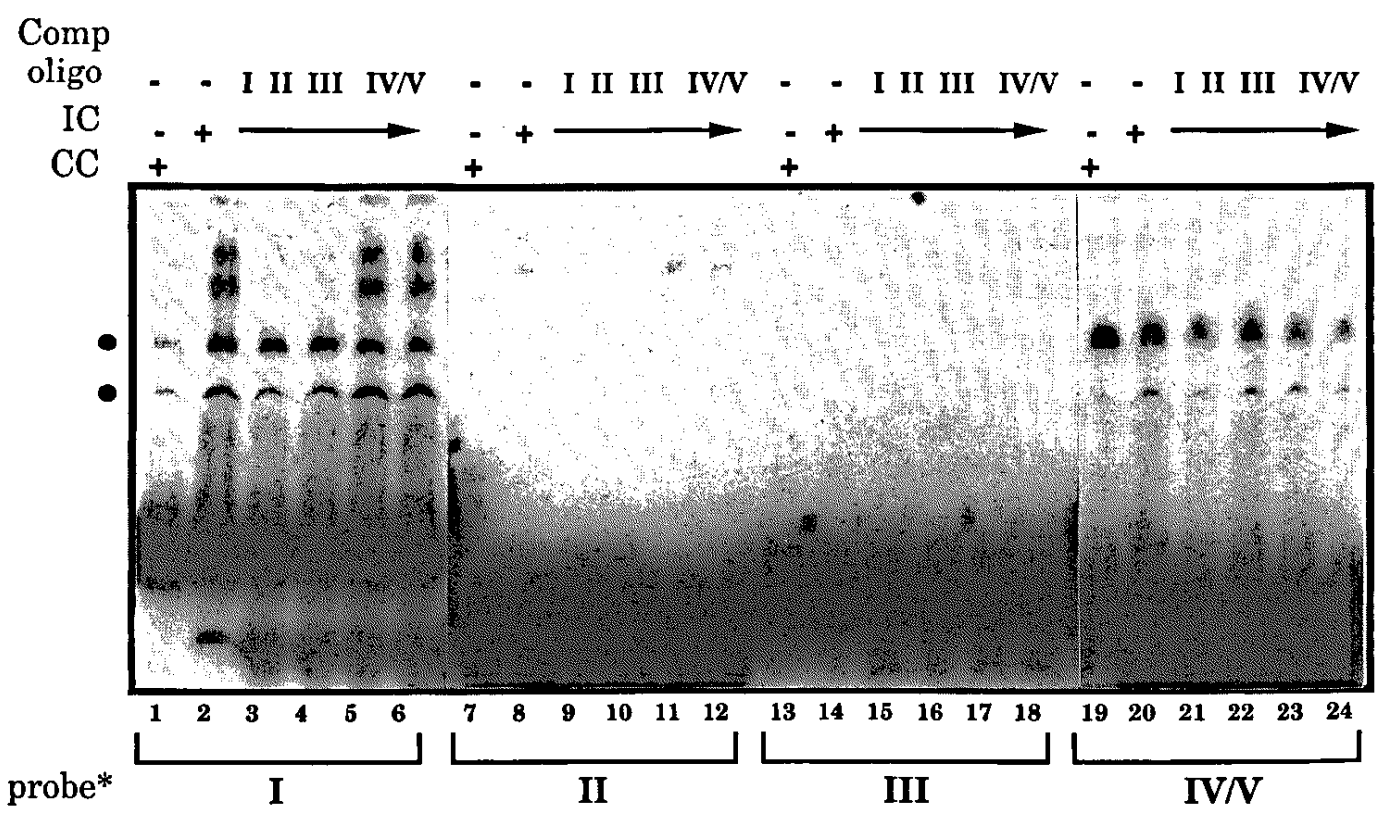

Figure 4. Gel shift assay with $m b n-2$ cells proteins and the labeled oligonucleotides I to IV/V. $5 \mu \mathrm{g}$ of proteins extracted from control untreated cells (CC) or LPS-treated cells (IC) was used. Competitions and legends are as in Fig. 2.

competed by probes I and II. The result differs from that obtained with the larval fat body in that the slowly migrating complex is not competed by an excess of probes III and IV/V (lanes 5-6). This could reflect some significant differences in the trans-acting factors which participate in the inducibility of the diptericin gene between the two systems (see above). The result obtained with probe II confirms the presence of a protein binding to the $\mathrm{kB}$ site in LPS-induced cells (lanes 7-8). Probe III does not bind any polypeptide in these cell extracts which is consistent with the result obtained in the competition experiment of probe I. Probe IV/V (lanes 19-24) revealed one complex which is not enhanced upon LPS challenge.

\section{DISCUSSION}

The data presented in this study are part of our long-term efforts to understand the induction of the innate, non-adaptive immune response of insects. We have focused here on the proximal promoter sequences of the diptericin gene, the expression of which follows classical acute phase response kinetics $(1,4)$. In this promoter, the role of the $\kappa$ B-related sequences has already been established by our previous experiments based on transgenic fly lines and transfected $m b n-2$ cells with wild type and mutated sequences $(8$, see also ref. 16 for the induction of the cecropin gene 
in Drosophila). The present study reveals that in addition to the $\mathrm{kB}$-related motifs, several other regulatory sequences are involved in the expression of this gene (see Fig.5). Indeed, in fat body and $m b n-2$ cells, several specific DNA-binding protein complexes are induced by immune challenge. Interestingly, the DNA motifs in the proximal promoter to which the proteins bind are all homologous to mammalian cis-regulatory sequences involved in the regulated expression of acute phase response genes, confirming the role of these motifs in the insect system. We can anticipate that the tissue-specific and bacteria-induced control of the diptericin gene results from the complex interplay of several partner proteins which may either cooperate or compete at their cognate binding sites. We note in particular that the major protected sequences are all present in two copies which increases the possibility of interactions. It is striking to see, for instance, that the probes containing the motifs homologous to NF-IL6RE and ICRE compete with the protein binding to the NF-kB-related site at its target. Our results are provocative in view of recent reports on the interactions of regulatory elements in the expression of acute phase response genes in mammals. Ohomori and Hamilton(17), for instance, noted a cooperative interaction between ISRE and $\kappa \mathrm{B}$-related sequence motifs in the control of IFN $\gamma$ - and LPS-stimulated transcription from the murine IP10 (inflammatory protein $10 \mathrm{kDa}$ ) promoter. In the IFN-stimulated
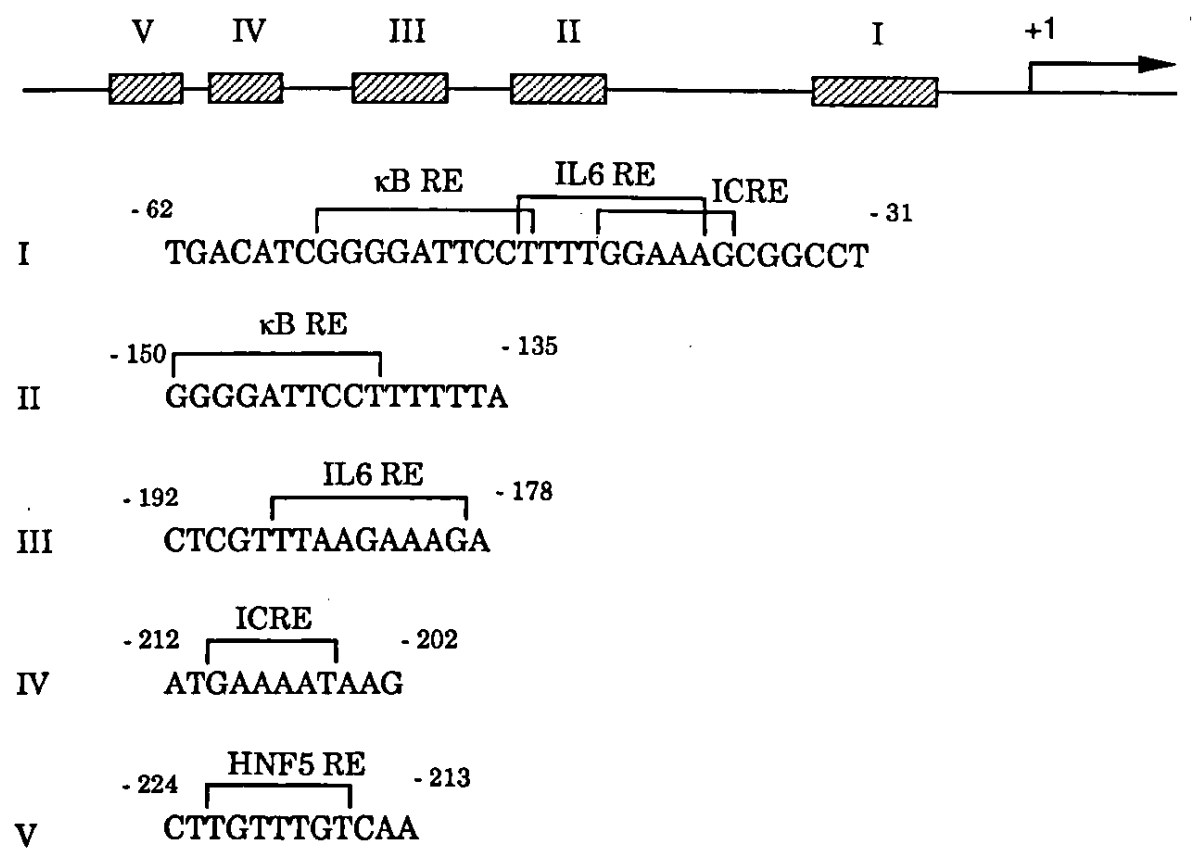

Figure 5 . Sequence of the protected regions $I$ to $V$ of the diptericin promoter. The consensus binding site for mammalian factors is indicated above the sequences. 
expression of class I genes of the MHC, Ten and associates (18) observed the interaction between an Interferon Response Factor and KBF1, the homodimer of the $\mathrm{p} 50$ subunit of $\mathrm{NF}-\mathrm{kB}$. In a similar context, the association of the transcription factor NF-IL6 and the p50 subunit of NF- $\mathrm{KB}$ was reported by LeClair et al. (19), and Li and Liao (20) presented data suggesting a cooperative interaction of a C/EBP-like binding site (NF-IL6 is a member of the C/EBP family of transcriptional activators; 21) in the cytokine-induced expression of the acute-phase protein serum amyloid A.

Finally our data raise the question whether insects actually produce during their immune response cytokines similar to those which in mammals mediate the acute-phase response. Although some evidence points to the existence of cytokine-like activities in invertebrates, no structural data exist up to now on insect cytokines. The Drosophila immune system appears as a favorable system to investigate this unsolved problem.

\section{ACKNOWLEDGMENT}

We are grateful to Pr. Elizabeth Gateff, Mainz, for a generous gift of $m b n-2$ cells.

\section{REFERENCES}

1. Hoffmann, J.A., Hetru, C. and Reichhart, J.M. (1993) FEBS Lett. 325, 63-66.

2. Hoffmann, J.A., Dimarcq, J.L. and Bulet, P. (1992) Médecine/Sciences $8,432-439$.

3. Hultmark, D. (1993) Trends in Genetics 9, 178-183.

4. Wicker, C., Reichhart, J.M., Hoffmann, D., Hultmark, D., Samakovlis, C. and Hoffmann, J.A. (1990) J. Biol. Chem. 265, 22493-22498.

5. Reichhart, J.M., Meister, M., Dimarcq, J.L., Zachary, D., Hoffmann D., Ruiz, C., Richards, G. and Hoffmann, J.A. (1992) EMBO J. 11, 1469-1477.

6. Gateff, E., Gissmann, L., Shrestha, R., Plus, N., Pfister, H., Schröder, J., and zur Hauzen, H. In Kurstak, E., Maramorosch, K., and Dübendorfer, A. (eds), "Invertebrate Systems in vitro". Elsevier/North Holland Biomedical Press. Amsterdam, pp 517-533.

7. Samakovlis, C., Asling, B., Boman, H.G., Gateff, E. and Hultmark, D. (1992) Biochem. Biophys. Res. Commun. 188, 1169-1175.

8. Kappler, C., Meister, M., Lagueux, M., Gateff, E., Hoffmann, J.A. and Reichhart, J.M. (1993) EMBO J. 12, 1561-1568.

9. Isshiki, H., Akira, S., Sugita, T., Nishio, Y., Hashimoto, S., Pawlowski, T., Suematsu, S. and Kishimoto, T. (1991) The New Biologist 3, 63-70.

10. Hocke, G.M., Barry, D. and Fey, G.H. (1992) Mol. Cell. Biol. 12, 22822294.

11. Dignam, J.D., Lebovitz, R.M. and Roeder, R.G. (1983) Nucleic Ac. Res. $11,1475-1489$.

12. Krummel, B. (1990) in Innis, M.A., Gelfand, D.H, Sninsky, J.J and White, T.J. (eds), "PCR protocols. A guide to methods and applications." Acad. Press. San Diego, pp 184-187.

13. Williams, B.R.G. (1991) Eur. J. Biochem. 200, 1-11. 
14. Zabel, U., Schreck, R. and Baeuerle, P.A. (1991) J. Biol. Chem. 266, 252-260.

15. Grange, T., Roux, J., Rigaud, G. and Pictet, R. (1991) Nucleic Ac. Res. 19, 131-139.

16. Engström, Y., Kadalayil, L., Sun, S.C., Samakovlis, C., Hultmark, D. and Faye, I. (1993) J. Mol. Biol. 232, 327-333.

17. Ohomori, Y. and Hamilton, T.A. (1993) J. Biol. Chem. 268, 6677-6688.

18. Ten, R.M., Blank, V., Le Bail, O., Kourilsky, P. and Israël, A. (1993) C. R. Acad. Sci. Paris, Sciences de la vie/Life sciences 316, 496-501.

19. LeClair, P.K., Blanar, M.A. and Sharp, P.A. (1992) Proc. Natl. Acad. Sci. USA. 89, 8145-8149.

20. Li, X. and Liao, W.S.L. (1992) Nucleic Ac. Res. 20, 4765-4772.

21. Akira, S., Isshiki, H., Sugita, T., Tanabe, O., Kinoshita, S., Nishio, Y., Nakajima,T., Hirano, T. and Kishimoto T. (1990) EMBO J. 9, 18971906. 